\title{
Controlled trial of fresh frozen plasma in asphyxiated low birthweight infants
}

\author{
G. HAMBLETON and W. J. APPLEYARD* \\ From St. Thomas' Hospital, London
}

\begin{abstract}
Hambleton, G., and Appleyard, W. J. (1973). Archives of Disease in Childhood, 48, 31. Controlled trial of fresh frozen plasma in asphyxiated low birthweight infants. A controlled trial of fresh frozen plasma in asphyxiated newborn infants weighing less than $2.5 \mathrm{~kg}$ is reported, together with coagulation and other data obtained from the infants. The findings based on 66 infants were as as follows. (1) There was no evidence that infusion of fresh frozen plasma prevented intraventricular haemorrhage. (2) Thrombotest did not appear to be a useful discriminant test for 'at risk' infants. (3) Asphyxiated low birthweight infants do not respond to vitamin $K_{1}$ in respect of thrombotest or prothrombin time. (4) The initial coagulation status of small-for-dates infants could not be distinguished from normal premature infants.
\end{abstract}

The importance of hypoxia in the pathogenesis of intracranial haemorrhage in low birthweight infants is well recognized (Frederick and Butler, 1970; Towbin, 1968). The exact mechanism is still not fully understood, but it has been suggested that hypoxia may cause defects in coagulation (Chadd et al. 1971) and that it is those infants with prolonged clotting tests who are particularly at risk from cerebral haemorrhage (Gray, Ackerman, and Fraser, 1968).

On this basis, Gray et al. have advocated the infusion of fresh frozen plasma to correct the deficiencies of clotting factors. In an uncontrolled trial of this therapy, given to low birthweight infants who had thrombotest levels under $10 \%$, they claimed a reduction of mortality in the treated infants from a previously expected $19 \%$ to $4 \%$. In the study, $46 \%$ of those infants who had suffered from an episode of birth asphyxia were found to have thrombotest values under $10 \%$, indicating a particular risk from intracranial haemorrhage as identified in a previous study (Gray and Smith, 1966). In a smaller series, Appleyard and Cottom (1970) did not find any significant difference in the thrombotest values at birth between normal and asphyxiated low birthweight infants. However, the thrombotest values of the 'normal' infants rose significantly over the first 24 hours after the adminis-

\footnotetext{
Received 30 May 1972.

^Present address: Kent and Canterbury Hospital, Canterbury, Kent.
}

tration of vitamin $K_{1}$, whereas the low birthweight infant who had suffered from birth asphyxia failed to show any improvement. From these results it was apparent that an episode of hypoxia was a better indication of those low birthweight infants at risk from intracranial haemorrhage than the initial coagulation status as measured by the thrombotest. In view of the apparent protective effect of the fresh frozen plasma, a controlled trial of the use of fresh frozen plasma in infants of low birthweight who had suffered from significant birth asphyxia has been instituted to evaluate the effect on the coagulation status, and to seek any difference in mortality or morbidity between the treated and untreated groups. Our initial results are presented in this paper.

\section{Subjects and methods}

Neonates weighing less than $2500 \mathrm{~g}$ who required resuscitation at birth (Apgar 4 at 5 minutes, Aberdeen Class C or D) were randomly allocated to control or treatment groups. Venous samples of blood were withdrawn into citrate and sequestrene tubes at 0 to 6 , 24, and 48 hours. Thrombotest (Owren, 1959), prothrombin time (Quick, 1942), and partial thromboplastin time (Langdell, Wagner, and Brinkhous, 1953) were performed and the haemoglobin concentration estimated. Treatment consisted of two infusions of fresh frozen plasma $(10 \mathrm{ml} / \mathrm{kg})$, the first at 0 to 6 hours after the first sample was collected, the second at 24 hours after birth.

Sixty-six babies entered the trial: 35 were normal 
TABLE I

Weights and gestations of infants admitted to trial

\begin{tabular}{|c|c|c|c|c|c|}
\hline & \multirow{2}{*}{ No. } & \multicolumn{2}{|c|}{ Birthweight (kg) } & \multicolumn{2}{|c|}{ Gestational age (wk) } \\
\hline & & Mean & Range & Mean & Range \\
\hline All babies & 66 & $1 \cdot 81$ & $0 \cdot 88-2 \cdot 45$ & 35 & $27-42$ \\
\hline Control & 33 & $1 \cdot 88$ & $0 \cdot 97-2 \cdot 41$ & 35 & $28-42$ \\
\hline Treated & 33 & $1 \cdot 85$ & $0 \cdot 88-2 \cdot 45$ & 35 & $27-40$ \\
\hline Premature & 35 & $1 \cdot 85$ & $0 \cdot 88-2 \cdot 45$ & 33 & $27-38$ \\
\hline SHID & 31 & $1 \cdot 9$ & $0 \cdot 98-2 \cdot 38$ & 37 & $32-42$ \\
\hline
\end{tabular}

SFID, small-for-dates.

weight for gestation, 31 were small-for-dates (Tanner and Thomson, 1970). There were 33 controls (16 premature, $17 \mathrm{SFD}$ ) and 33 received treatment (19 premature, $14 \mathrm{SFD})$. The means and ranges of gestational ages and birthweights of the babies are shown in Table I. For technical reasons it was not possible to perform coagulation studies on all the babies on every occasion. The number of babies who were investigated is indicated in the tables.

\section{TABLE II}

Mean thrombotest values ( ${ }^{\circ}$ ) in asphyxiated low birthweight infants aet. 0 to 6 hours $(n=39)$

\begin{tabular}{lcc|c|c}
\hline & $\begin{array}{c}\text { Thrombotest } \\
\%\end{array}$ & SD & SE & $\begin{array}{c}\text { No. } \\
<10 \%\end{array}$ \\
\hline $\begin{array}{lll}\text { Uncorrected } \\
\text { Corrected for } \mathrm{Hb}\end{array}$ & $\begin{array}{l}21 \cdot 8 \\
24 \cdot 8\end{array}$ & $\begin{array}{l}11 \cdot 7 \\
15 \cdot 0\end{array}$ & $\begin{array}{c}1 \cdot 7 \\
2 \cdot 1\end{array}$ & 5 \\
\hline
\end{tabular}

\section{Results}

Initial thrombotest values. Table II shows the mean thrombotest values of all babies aet. 0 to 6 hours. All the results were corrected for $\mathrm{Hb}$ concentration. 5 infants had values less than $10 \%$; 42 out of the 49 infants in whom the test was performed had values less than $35 \%$. The Fig. shows the range and distribution of initial thrombotest values. There was no difference between those infants of normal weight and those small-fordates (Table III).

\section{Response to treatment.}

Thrombotest. Table III shows thrombotest $\vec{\omega}$ values of the control and treated groups over the

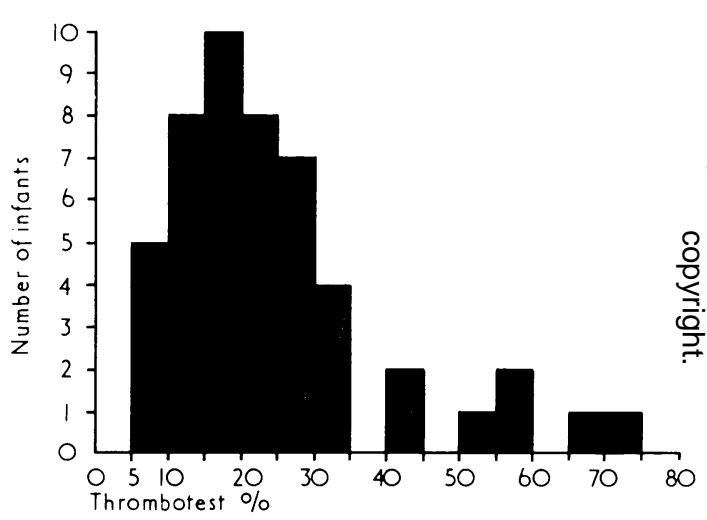

FIG.-Distribution of thrombotest values in asphyxiated low birthweight infants.

first 48 hours of life, and a comparison of normal $\stackrel{?}{\circ}$ and small-for-dates infants. None of the changes is statistically significant (Student ' $t$ ' test).

TABLE III

Thrombotest values $\% \div S D$ during the first 48 hours of life ( $n$ values in brackets)

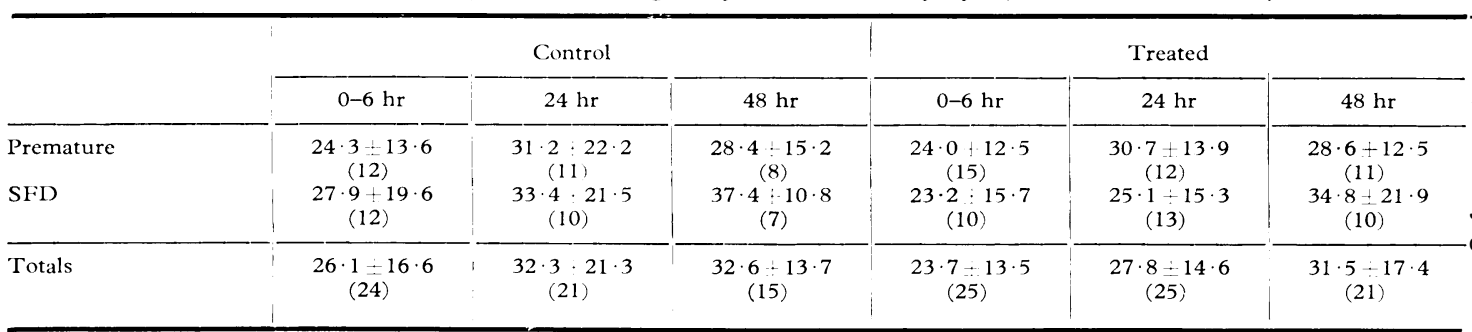

SFD, small-for-dates. 
TABLE IV

Prothrombin ratios in the first 48 hours of life ( $n$ values in brackets)

\begin{tabular}{|c|c|c|c|c|c|c|}
\hline & \multicolumn{3}{|c|}{ Control } & \multicolumn{3}{|c|}{ Treated } \\
\hline & $0-6 \mathrm{hr}$ & $24 \mathrm{hr}$ & $48 \mathrm{hr}$ & $0-6 \mathrm{hr}$ & $24 \mathrm{hr}$ & $48 \mathrm{hr}$ \\
\hline $\begin{array}{l}\text { Premature } \\
\text { SFD }\end{array}$ & $\begin{array}{c}1 \cdot 56 \pm 0 \cdot 58 \\
(12) \\
1 \cdot 91 \pm 1 \cdot 06 \\
(14)\end{array}$ & $\begin{array}{c}1 \cdot 45 \pm 0 \cdot 44 \\
(10) \\
1 \cdot 47 \pm 0 \cdot 45 \\
(14)\end{array}$ & $\begin{array}{c}1 \cdot 64 \pm 1 \cdot 23 \\
(7) \\
1 \cdot 55 \pm 0 \cdot 57 \\
(7)\end{array}$ & $\begin{array}{c}1 \cdot 47 \pm 0 \cdot 33 \\
(14) \\
1 \cdot 49 \pm 0 \cdot 39 \\
(13)\end{array}$ & $\begin{array}{c}1 \cdot 45 \pm 0 \cdot 27 \\
(11) \\
1 \cdot 55 \pm 0 \cdot 47 \\
(13)\end{array}$ & $\begin{array}{c}1 \cdot 40 \pm 0 \cdot 27 \\
(10) \\
1 \cdot 27 \pm 0 \cdot 19 \\
(10)\end{array}$ \\
\hline Totals & $\begin{array}{c}1 \cdot 75 \pm 0 \cdot 88 \\
(26)\end{array}$ & $\begin{array}{c}1 \cdot 46 \pm 0 \cdot 44 \\
(24)\end{array}$ & $\begin{array}{c}1 \cdot 60 \pm 0 \cdot 92 \\
(14)\end{array}$ & $\begin{array}{c}1 \cdot 48 \pm 0 \cdot 35 \\
(27)\end{array}$ & $\begin{array}{c}1 \cdot 51 \pm 0 \cdot 39 \\
(24)\end{array}$ & $\begin{array}{c}1 \cdot 33 \pm 0 \cdot 23 \\
\quad(20)\end{array}$ \\
\hline
\end{tabular}

SFD, small-for-dates.

Prothrombin times. Table IV gives values over the first 48 hours. Treatment appears to reverse the expected deterioration seen in the control group, but none of the changes was statistically significant. The premature and small-for-dates infants also show no significant differences; further analysis also showed no difference in initial prothrombin ratios when the premature and small-fordates infants were compared (Table VI).

Partial thromboplastin times. Initial PTTs are the same in all four groups.

Table $\mathrm{V}$ shows that there is a tendency for PTT to improve in the first 24 hours in the control group as well as in the treated group. A similar pattern is seen when normal and SFD infants are compared. The SFD infants appear to respond to treatment by 48 hours better than normal premature infants.

Small-for-dates infants aet. 0 to 6 hours. Table VI shows data comparing SFD and premature infants during the first 6 hours of life. The mean gestational age of the premature group was 4 weeks less than the small-for-dates infants. There was no significant difference between them in the coagulation status as measured by the

TABLE V

Geometric means of prolongation of partial thromboplastin time over control (seconds) ( $n$ values in brackets)

\begin{tabular}{|c|c|c|c|c|c|c|}
\hline & \multicolumn{3}{|c|}{ Control } & \multicolumn{3}{|c|}{ Treated } \\
\hline & $0-6 \mathrm{hr}$ & $24 \mathrm{hr}$ & $48 \mathrm{hr}$ & $0-6 \mathrm{hr}$ & $24 \mathrm{hr}$ & $48 \mathrm{hr}$ \\
\hline Premature & $\begin{array}{l}30 \cdot 8 \\
(12)\end{array}$ & $\begin{array}{l}9.1 \\
(9) \\
P<0.05\end{array}$ & $\begin{array}{c}12 \cdot 7 \\
(7)\end{array}$ & $\begin{array}{l}20 \cdot 0 \\
(13)\end{array}$ & $\begin{array}{l}21 \cdot 4 \\
(13)\end{array}$ & $\begin{array}{l}19 \cdot 2 \\
(11)\end{array}$ \\
\hline SFD & $\begin{array}{l}17 \cdot 9 \\
(13)\end{array}$ & $\begin{array}{c}9 \cdot 1 \\
(11)\end{array}$ & $\begin{array}{l}9 \cdot 0 \\
(7)\end{array}$ & $\begin{array}{l}31 \cdot 14 \\
(13)\end{array}$ & $\begin{array}{l}21 \cdot 1 \\
(13)\end{array}$ & $\begin{array}{c}6.9 \\
P \stackrel{(10)}{<0.001}\end{array}$ \\
\hline Totals & $\begin{array}{l}23 \cdot 2 \\
(25)\end{array}$ & $\begin{array}{c}9.1 \\
\stackrel{(20)}{P}<0.02\end{array}$ & $\begin{array}{l}10 \cdot 7 \\
(14)\end{array}$ & $\begin{array}{l}25 \cdot 0 \\
(26)\end{array}$ & $\begin{array}{l}21 \cdot 2 \\
(26)\end{array}$ & $\begin{array}{c}11.8 \\
(21) \\
P \stackrel{<0.02}{l}\end{array}$ \\
\hline
\end{tabular}

TABLE VI

Coagulation studies in asphyxiated low birthweight infants aet. 0 to 6 hours ( $n$ values in brackets)

\begin{tabular}{|c|c|c|c|c|c|}
\hline & $\begin{array}{c}\text { Mean } \\
\text { gestational } \\
\text { age (wk) }\end{array}$ & $\begin{array}{c}\text { Mean } \\
\text { birthweight } \\
(\mathrm{kg})\end{array}$ & $\begin{array}{c}\text { Thrombotest } \\
(\%)\end{array}$ & $\begin{array}{l}\text { Prothrombin } \\
\text { ratios }\end{array}$ & $\begin{array}{c}\text { Mean } \\
\text { prolongation } \\
\text { PTT (sec) }\end{array}$ \\
\hline $\begin{array}{l}\text { Premature } \\
\text { SFD }\end{array}$ & $\begin{array}{l}33 \\
37\end{array}$ & $\begin{array}{l}1 \cdot 85 \\
1 \cdot 90\end{array}$ & $\begin{array}{c}24 \cdot 1 \pm 12 \cdot 7 \\
\quad(27) \\
25 \cdot 8 \pm 17 \cdot 7 \\
\quad(22)\end{array}$ & $\begin{array}{c}1 \cdot 51 \pm 0 \cdot 45 \\
(26) \\
1 \cdot 71 \pm 0 \cdot 83 \\
(27)\end{array}$ & $\begin{array}{l}24 \cdot 6 \\
(25) \\
23 \cdot 6 \\
(26)\end{array}$ \\
\hline
\end{tabular}

PTT, partial thromboplastin times; SFD, small-for-dates. 
thrombotests, prothrombin ratios, and partial thromboplastin times.

Effect of fresh frozen plasma (FFP) in preventing intracranial haemorrhage. Table VII

\section{TABLE VII}

Comparison of deaths and incidence of cerebral haemorrhage in asphyxiated low birthweight infants

\begin{tabular}{l|c|cc|c|c}
\hline & $\begin{array}{c}\text { No. of } \\
\text { patients }\end{array}$ & $\begin{array}{c}\text { No. of } \\
\text { deaths }\end{array}$ & $\begin{array}{c}\text { No. of } \\
\text { necropsies }\end{array}$ & IVH & $\begin{array}{c}\text { Other } \\
\text { ICH }\end{array}$ \\
\hline \begin{tabular}{c|ccc} 
Control \\
Treated
\end{tabular} & 33 & 10 & 7 & 0 & 2 \\
& 33 & 9 & 7 & 3 & 0 \\
\hline IVH, intraventricular & haemorrhage; & ICH, intracranial
\end{tabular}
haemorrhage.

shows that 3 babies in the treated group died with intraventricular haemorrhage, proven at necropsy. In the control group there was 1 infant who showed a tentorial tear at necropsy, and another who had subarachnoid haemorrhage alone. A further infant in the control group survived the neonatal period after several days on a ventilator, but by the age of 6 months had obvious microcephaly. None of the babies who died with intracranial haemorrhage was smallfor-dates. The 3 babies who died from intraventricular haemorrhage were all of 27 or 28 weeks' gestation.

Table VIII summarizes the coagulation data on these infants. Only one of their initial thrombotests was under $10 \%$ and all were less than $20 \%$, though the Fig. shows that 23 out of 49 initial thrombotests on the other low birthweight infants were also below this level.

\section{Discussion}

The results fail to confirm that thrombotest is of any value as a screening test for low birthweight infants at risk from intracranial haemorrhage. From the data in Tables II, III, and VIII, and the
Fig., it would be exceedingly difficult to choose a $\frac{}{\omega}$. value below which a particular risk applies, and the $\Omega$ thrombotest values of the infants who died with intracranial haemorrhage do not show a consistent. pattern.

The initial values of PT ratios and PTT are 0 similar to those cited for term babies by Aballi 등 and Lamerens (1962) and by Hathaway (1970). $\frac{\bar{\rho}}{2}$ This suggests that being premature, small-fordates, or hypoxic at birth does not affect the initial levels of these clotting functions. The fresh frozen plasma does not result in any real improvement in either the thrombotest or prothrombin times, though there was a significant change in the partial thromboplastin times in small-for-dates infants so treated.

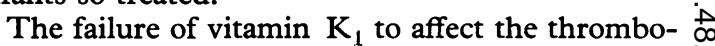
test values or prothrombin ratios in asphyxiated $\rightarrow$ low birthweight infants over the first 24 hours is $\omega$ confirmed in Tables III and IV. The fact that 0 there is no subsequent deterioration shown in the results suggests that this is due to interference in $c$ liver function rather than to disseminated intravascular coagulation.

Small-for-dates babies cannot be distinguished from normal premature infants as judged by the $\vec{\varphi}$ coagulation data obtained in this trial. The resulte $\omega$ do not confirm a recent suggestion that such infants are initially deficient in vitamin $\mathrm{K}_{1}$-depene dent liver factors (Chessells and Wigglesworth 1971).

We have found no evidence that fresh frozen plasma prevents intraventricular haemorrhage. The infants in the trial are being followed up with periodic developmental assessments. So far there are no apparent differences between the two groups. It is established that heparinized, fresh plasma should be given to those infants who have the clinical appearance of secondary haemorrhagic disease proved by laboratory investigation (Leissring and Vorlicky, 1968; Skyberg and Jacobsen, 1969). However, the use of fresh frozen plasma

TABLE VIII

Some data relating to infants dying with intracranial haemorrhage

\begin{tabular}{|c|c|c|c|c|c|c|c|c|c|c|c|c|}
\hline \multirow{2}{*}{ Case no. } & \multirow{2}{*}{$\begin{array}{l}\text { Birthweight } \\
(\mathrm{kg})\end{array}$} & \multirow{2}{*}{$\begin{array}{c}\text { Gestation } \\
\text { (wk) }\end{array}$} & \multirow{2}{*}{$\begin{array}{c}\mathrm{T} \\
\text { or } \\
\mathrm{C}^{\star}\end{array}$} & \multicolumn{3}{|c|}{ Thrombotest ( $\%)$} & \multicolumn{3}{|c|}{ Prothrombin ratio } & \multicolumn{3}{|c|}{ Prolongation PTT } \\
\hline & & & & $0-6 \mathrm{hr}$ & $24 \mathrm{hr}$ & $48 \mathrm{hr}$ & $0-6 \mathrm{hr}$ & $24 \mathrm{hr}$ & $48 \mathrm{hr}$ & $0-6 \mathrm{hr}$ & $24 \mathrm{hr}$ & $48 \mathrm{hr}$ \\
\hline $\begin{array}{l}1 \\
2 \\
3 \\
4 \\
5\end{array}$ & $\begin{array}{l}1 \cdot 58 \\
2 \cdot 3 \\
1 \cdot 2 \\
1 \cdot 15 \\
1 \cdot 22\end{array}$ & $\begin{array}{l}31 \\
33 \\
27 \\
27 \\
28\end{array}$ & $\begin{array}{l}C \\
C \\
T \\
T \\
T\end{array}$ & $\begin{array}{r}- \\
9 \cdot 2 \\
18 \cdot 2 \\
12 \cdot 2 \\
18 \cdot 0\end{array}$ & $\begin{array}{l}\overline{9 \cdot 0} \\
\overline{14 \cdot 0} \\
17 \cdot 0\end{array}$ & 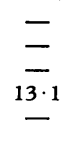 & $\begin{array}{l}1 \cdot 95 \\
2 \cdot 3 \\
1 \cdot 52 \\
2 \cdot 45 \\
1 \cdot 60\end{array}$ & $\begin{array}{c}2 \cdot 46 \\
- \\
1 \cdot 76 \\
1 \cdot 47\end{array}$ & $\begin{array}{c}- \\
\overline{1 \cdot 62} \\
1 \cdot 37\end{array}$ & $\begin{array}{l}21 \cdot 3 \\
22 \cdot 7 \\
48 \\
137 \cdot 0 \\
21 \cdot 4\end{array}$ & $\begin{array}{l}66 \cdot 5 \\
- \\
- \\
81 \cdot 4 \\
21 \cdot 7\end{array}$ & $\begin{array}{l}- \\
\overline{74 \cdot 4} \\
14 \cdot 4\end{array}$ \\
\hline
\end{tabular}


as a prophylactic measure cannot be recommended on the results of this trial.

We wish to thank the sisters, midwives, and nursing staff of the premature baby units in the St. Thomas' Hospital Group for their invaluable help and cooperation, and Miss Angela Brinton for technical assistance. We also thank Dr. G. I. C. Ingram for advice about the coagulation studies, and the hospital's Department of Social Medicine for advice about the design of the trial.

The work was supported by a grant from the Worshipful Company of Dyers.

\section{REFERENCES}

Aballi, A. J., and Lamerens, S. de (1962). Coagulation changes in the neonatal period and in early infancy. Pediatric Clinics of North America, 9, 785.

Appleyard, W. J., and Cottom, D. G. (1970). Effect of asphyxia on thrombotest values in low birthweight infants. Archives of Disease in Childhood, 45, 705.

Chadd, M. A., Elwood, P. C., Gray, O. P., and Muxworthy, S. M. (1971). Coagulation defects in hypoxic full-term newborn infants. British Medical fournal, 4, 516.

Chessells, J. M., and Wigglesworth, J. S. (1971). Coagulation studies in severe birth asphyxia. Archives of Disease in Childhood, 46, 253.

Frederick, J., and Butler, N. R. (1970). Certain causes of neonatal death. II. Intraventricular haemorrhage. Biology of the Neonate, 15, 257.
Gray, O. P., Ackermann, A., and Fraser, A. J. (1968). Intracranial haemorrhage and clotting defects in low-birth-weight infants. Lancet, 1, 545.

Gray, O. P., and Smith, S. G. (1966). The thrombotest on the first day of life. Acta Paediatrica Scandinavica, 55, 563.

Hathaway, W. E. (1970). Coagulation problems in the newborn infant. Pediatric Clinics of North America, 17, 929.

Langdell, R. D., Wagner, R. H., and Brinkhous, K. M. (1953). Effect of antihemophilic factor on one-stage clotting tests. A presumptive test for hemophilia and a simple one-stage antehemophilic factor assay procedure. fournal of Laboratory and Clinical Medicine, 41, 637.

Leissring, J. C., and Vorlicky, L. N. (1968). Disseminated intravascular coagulation in a neonate. American fournal of Diseases of Children, 115, 100.

Owren, P. A. (1959). 'Thrombotest' : a new method for controlling anticoagulant therapy. Lancet, 2, 754.

Quick, A. J. (1942). The Haemorrhagic Diseases and the Physiology of Hemostasis. C. C. Thomas, Springfield, Illinois.

Skyberg, D., and Jacobsen, C. D. (1969). Defibrination syndrome in a newborn, and its treatment with exchange transfusion. Acta Paediatrica Scandinavica, 58, 83.

Tanner, J. M., and Thomson, A. M. (1970). Standards for birthweight at gestation periods from 32 to 42 weeks, allowing for maternal height and weight. Archives of Disease in Childhood, 45, 566 .

Towbin, A. (1968). Cerebral intraventricular haemorrhage and subependymal matrix infarction in the fetus and premature newborn. American fournal of Pathology, 52, 121.

Correspondence to Dr. G. Hambleton, Institute of Child Health, Hammersmith Hospital, Du Cane Road, London W.12. 